\title{
Attitudes of the Elderly towards Interprofessional Cooperation and Collaborative Pharmacy Practices: Questionnaire development
}

\author{
Velibor O. Ilić ${ }^{1 *}$, Ljiljana Tasić ${ }^{1}$, Valentina Marinković ${ }^{1}$ \\ ${ }^{1}$ University of Belgrade - Faculty of Pharmacy, Department of Social Pharmacy and \\ Pharmaceutical Legislation, Vojvode Stepe 450, 11221 Belgrade, Serbia \\ * Corresponding author: Velibor O. Ilić, E-mail: ivelibor@gmail.com.
}

\begin{abstract}
Population aging is progressing at the highest rate historically, leading to an increased morbidity. Therefore, higher levels of collaborative pharmaceutical practice (CPP) and interprofessional collaboration (IPC) are expected to provide the necessary improvement to the healthcare system performance. For a strong body of literature to be built in the area of CPP and IPC, methodologically sound research studies must be completed, using questionnaires with welldeveloped psychometric properties. Therefore, the objective was to develop a questionnaire aimed at researching the attitudes of the elderly $(65+)$ towards IPC and CPP. A structured questionnaire was developed using the Delphi method by a team of experts $(n=8)$ within four rounds of meetings. Reliability, question correlation and factor analysis were used for questionnaire validation. Questionnaire validation $(n=40)$ determined the Cronbach's Alpha to be at the high value of 0.774 , and reliability analysis of questionnaire's scales on the total sample $(\mathrm{n}=185)$ in the five Geriatric Centers confirmed a relatively high value of 0.736 . Interclass correlation coefficient values were highly significant $(\mathrm{ICC}=0.749 ; \mathrm{p}<0.01$ ), which confirmed questionnaire compactness regarding CPP. An exploratory factor analysis highlighted 2 significant factors explaining $53 \%$ of the entire model variability. Both questionnaire validation $(n=40)$ and total sample analysis $(n=185)$ confirmed the appropriateness of the developed questionnaire.
\end{abstract}

Keywords: questionnaire development, collaborative practice, attitudes of the elderly, Delphi method 


\section{Introduction}

As a consequence of increased life expectancies and declining birth rates (1), population aging is taking place at the highest rate in recorded history (2), and the percentage of the population over 60 is growing faster than any other age group in almost all countries (3). By 2050, it is expected that every fifth person will be older than 60 (4). Population aging leads to an increase in morbidity, especially in the incidence and prevalence of chronic diseases/conditions, as well as comorbidity (5). Bearing in mind the increasing health and social problems accompanying the elderly, it is necessary for future efforts of the healthcare and social services system to be directed towards the most adequate ways of fulfilling the growing demands facing them. Therefore, many decision makers have recognized the importance of collaborative practice and introduced operating models into the healthcare systems of their countries.

For a strong body of literature to be built in the area of collaborative pharmacy practice (CPP) and interprofessional collaboration (IPC) (6), conceptually and methodologically sound research studies must be completed. For quantitative research, this requires questionnaires with well-developed psychometric properties. As Ilic VO. stated (6), "Thannhauser J. and associates (7) found that most of the tools for measuring varying aspects of IPC (questionnaires predominately) were lacking detailed information with regard to their psychometric properties". Although there is no literature scarcity in the field of developing questionnaires for health care related research (8-13), the majority of them assessed only collaborations within a narrow health discipline, and almost exclusively just from the perspective of healthcare professionals, while leaving patients' attitudes toward healthcare collaboration unexplored (6). Furthermore, due to the previously stated, the fact that many of the developed questionnaires were used only once, and that some papers did not include questionnaires in the appendix, the usability of those questionnaires in our research is limited (6). On the other hand, the most commonly used and widely assessed tools that are patient-oriented are questionnaires developed to measure the patients' quality of life $(14,15)$, predominantly used in clinical settings.

In the latest articles, there has been an evident shift from patient reported outcome measures (PROMs) to patient reported experience measures (PREMs) (16, 17). Although PROMs and its instruments (EQ-5D and AQoL for measuring the quality of life; NPRS for symptoms of pain and FSS for fatigue symptoms; K10 and PHQ-2 for depression and GAD7 for anxiety; WHODAS 2.0 and ODI for functional ability; SF-36 for self-reported health status; GSE for self-efficacy) are relevant tools with well proven clinical implication, the authors expect that in the future there will be more studies like the article by Singer SJ and associates, designed to measure integrated care (18).

Current literature has not provided us with an adequate instrument for use in this broad capacity. Therefore, the authors think that, for the purpose of this paper, it is necessary to develop a questionnaire for examining the attitudes and beliefs of senior $(65+)$ citizens (as users of healthcare and social services) towards interprofessional cooperation and collaborative practice, as well as towards the opportunities, methods, and solutions for their improvement in Serbia. Furthermore, the developed questionnaire with 
detailed methodology and provided psychometric properties can be a valuable tool and resource for other researchers of CPP and IPC.

The aim of the study was to develop a questionnaire with a view to researching the attitudes of the elderly people (65+) towards IPC and CPP. The newly developed questionnaire will be named "Elderly attitudes towards Interprofessional Cooperation and Collaborative Practice Instrument (EaICCP)"

\section{Methods}

\section{The questionnaire development and preliminary validation}

The development and preliminary validation of the questionnaire was done using the Delphi method. The questionnaire was developed within the four rounds of meetings of the expert team, which took place from October 2016 to February 2017. After obtaining the necessary Ethical approval, the preliminary validation of the questionnaire (6) was conducted. The questionnaire development was carried out in three steps: (i) Expert team formation, (ii) Identification of key problems and barriers to interprofessional and interdisciplinary cooperation between the healthcare and social services, (iii) Questions assessment. As the first step, an interprofessional and interdisciplinary team of experts convened, performing the identification (in a holistic manner) of the biggest challenges and obstacles experienced in practice (providing further potential questions for the questionnaire), regarding interprofessional and interdisciplinary cooperation within the scope of health- and social care for the elderly. Further on, a team of 8 participants was created, comprising: (6) a moderator, who managed the entire analyzing process (the chief researcher); experts on the process of dispensing medicines (pharmacists with Bachelor's or Master's degree employed in private and state-owned community pharmacies in the Republic of Serbia); experts on diagnosis, prescribing therapy, and treatment (general practitioners and/or physicians specialists), health professionals (nurses/medical technicians) involved in providing care, preparation and application of prescribed therapies on patients in geriatric homes; as well as social services experts (social workers); and an elderly person (6). Potential questions that would be included in the questionnaire, which were generated during the arranged meetings, were organized into three categories: (6) (i) socio-demographic features of respondents, (ii) elderly people's views on healthcare and social policies (iii) attitudes of the elderly as patients/geriatric users regarding the teamwork and interprofessional practice of healthcare workers within the context of improving the quality of life of the elderly. The second part of the questionnaire refers to the interprofessional practice (policies) in the broad sense, whereas the third part of the questionnaire refers to the collaborative practice as an integral part of the healthcare, as proposed in the conceptual CPP model (19). As the third step, the assessment process started at a joint group meeting, by grading the questions on a scale from 5 to 10. The questions with an average grade greater than the threshold values of 78 , became part of the final questionnaire automatically. Content validity was performed through Delphi method consensus (20). It was originally planned for the statistical 
overview of the obtained results to be e-mailed to the expert teams' members, in order for them to express their opinions as to whether the issues with the threshold values should be included or excluded from the questionnaire. In this case, only the responses attaining more than $75 \%$ of the consensus would be included in the final questionnaire, and the comments of the experts would be taken for consideration regarding any eventual corrections of the questions. Nevertheless, since there were no questions graded within the threshold values, the team gave its approval to the final form and the contents of the questionnaire. After that, a preliminary validation of the questionnaire was performed on a sample of $40(21,22)$ users of the geriatric center, by using the Cronbach's Alpha as a statistical parameter for the reliability analysis of the part of the questionnaire with questions relating to the conceptual model of the collaborative pharmacy practice (19). Since the Delphi members were satisfied with the Cronbach's Alpha value from the preliminary validation, the authors received the approval to carry on with the research.

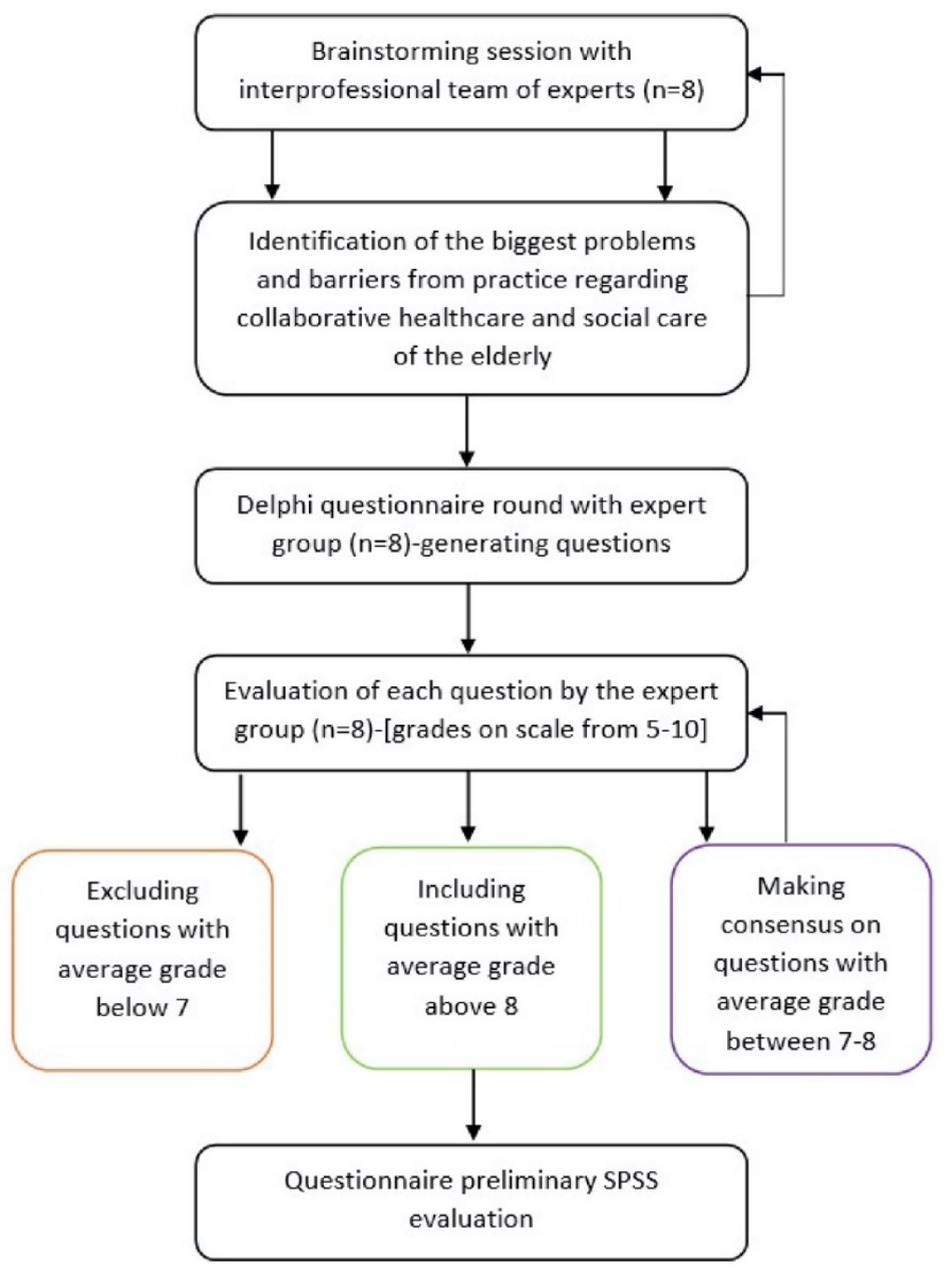

Figure 1. The development of the initial version of a questionnaire (EaICCP)

Slika 1. Razvoj inicijalne verzije upitnika (EaICCP) 


\section{Sampling and Setting}

Only $0.76 \%$ of the elderly in Serbia were able to secure accommodation in geriatric centres (23), while the available capacities were unevenly distributed, being predominately located at the north of Serbia (24). Therefore, the research was carried out in the Republic of Serbia, in its Autonomous Province of Vojvodina, Serbia's northern region, which consists of four geographical regions (Banat, Bačka, Srem and Mačva). In 2015, 12 publicly owned geriatric centers and 4 nursing homes were present in Vojvodina, along with 29 privately owned nursing homes, while only 8 of those privately owned nursing homes had obtained the necessary work licence. In that regard, using a stratified sampling method, the questionnaire was distributed to five publicly owned geriatric centers (GC Zrenjanin, GC Kikinda, GC Novi Sad, GC Subotica and GC Ruma) in cities located within the four previously mentioned geographic regions (Banat, Bačka, Srem and Mačva), thus encompassing the largest geriatric centers and their individual geriatric homes in the territory of AP Vojvodina (6). The inclusion criteria for the respondents were as follows: (6) The respondents were older than 65 years of age (average age 76.2 years) and were evaluated by the healthcare and social services workers of the geriatric centers to be sufficiently cognitively preserved to understand the questions from the questionnaire; the volunteers' willingness to participate; the ability to speak the Serbian language and the ability to speak clearly. At each GC there was one person delegated (a healthcare or social worker who was familiar with the research protocol) who would read the questions to respondents and fill out the questionnaire based on respondents' answers. A total of 200 questionnaires ( 40 questionnaires per GC) were mailed out by postal service or delivered in person. By July of 2017, a total of 187 Questionnaires were collected, all of which were valid (complete responses). Lastly, the answers of two respondents whose answers were extremely far from the $95 \%$ interval were eliminated from the statistical analysis.

\section{Statistical Analysis}

The data from the completed questionnaires were statistically processed using the IBM SPSS 22.0 software package and presented aggregately and exclusively for research purposes. In order to establish the reliability of our questionnaire, the Cronbach alpha coefficient and ICC (Intraclass correlation) coefficient were calculated. EFA (exploratory factor analysis) was performed in order to find the importance and pole of each question building our Questionnaire. Moreover, the correlation between questions was calculated. The significant level was always considered to be 0.05 .

\section{Ethical Considerations}

The Ethics Committee for Biomedical Research at the Faculty of Pharmacy, University of Belgrade, approved the research protocol and the created questionnaire, which was used as a survey instrument (approval number 1313/1 from 6.7.2017.) (6). Furthermore, after learning the details of the research protocol, written consent was obtained from all the directors of the Geriatric Centers where the research was to be 
conducted. After obtaining the approvals, the questionnaires were distributed by mail or in person. Filling out the questionnaire was completely voluntary, and the collected data were used aggregately and solely for scientific and research purposes, and so they shall never be displayed at the individual case level (6). Respondents were informed that by completing the questionnaire, they were giving informed consent to participate in the research.

\section{Results}

\section{Preliminary Validation of the Questionnaire}

Preliminary validation of the questionnaire, conducted on a sample of 40 respondents (the patients at the Geriatric Center) determined the value of the Cronbach's Alpha for the part of the questionnaire with questions related to the conceptual model of collaborative pharmacy practice, to be at the high value of 0.774 . Therefore, the same 40 questionnaires were added to the total sample.

Table I Descriptive parameters of question scores for questions 12-18

Tabela I Deskriptivni parametri skorova pitanja 12-18

\begin{tabular}{|l|l|l|l|l|l|}
\hline Questions & Minimum & Maximum & Mean & MED & SD \\
\hline $\begin{array}{l}\text { q12. Would a pharmacist, as a part of the health } \\
\text { care workers team improve health-related } \\
\text { outcomes and quality of life of the elderly? }\end{array}$ & 1.00 & 5.00 & 3.58 & 3.40 & 0.90 \\
\hline $\begin{array}{l}\text { q13. Rate the information provided by doctors } \\
\text { and pharmacists regarding products } \\
\text { prescribed/recommended to elderly patients? }\end{array}$ & 1.00 & 5.00 & 3.32 & 3.10 & 0.84 \\
\hline $\begin{array}{l}\text { q14. Would the efficiency of the Health Care } \\
\text { improve, if pharmacists would provide } \\
\text { counseling services regarding the rational and } \\
\text { safe use of pharmaceutical products for the } \\
\text { elderly patients? }\end{array}$ & 1.00 & 5.00 & 3.75 & 3.80 & 0.91 \\
\hline $\begin{array}{l}\text { q15. Assess the efficiency of the Health Care } \\
\text { System in regard to the time spent on } \\
\text { prescribing and issuing pharmaceutical } \\
\text { products to the elderly? }\end{array}$ & 1.00 & 5.00 & 2.80 & 3.00 & 0.83 \\
\hline $\begin{array}{l}\text { q16. Have you experienced a scenario where a } \\
\text { pharmacist notices a certain oversight in the } \\
\text { doctor's prescription/recommendation and asks } \\
\text { you to return to your doctor in order to have } \\
\text { him/her correct the error or to have the therapy } \\
\text { revised? }\end{array}$ & 1.00 & 5.00 & 2.21 & 2.50 & 1.07 \\
\hline $\begin{array}{l}\text { q17. Would the efficiency of the Healthcare } \\
\text { system increase if there were an even better } \\
\text { cooperation and coordination between doctors } \\
\text { and pharmacists and other health care workers } \\
\text { providing care for the elderly? }\end{array}$ & 1.00 & 5.00 & 3.76 & 3.65 & 0.83 \\
\hline $\begin{array}{l}\text { q18. Have you experienced a power outage or } \\
\text { a computer system crash at the Community } \\
\text { Health Care Center or a pharmacy? }\end{array}$ & 1.00 & 4.00 & 2.02 & 2.20 & 0.95 \\
\hline
\end{tabular}




\section{Total sample qestionnaire validation}

\section{Reliability analysis}

All questions regarding the CPP (third part of the questionnaire) were scored in the same way, using the Likert scale. The minimum value (score 1) in table 1 would mean that the respondents believe that there is a complete absence of the CPP, and/or their negative attitudes towards CPP. The maximum value (score 5) would express an ideal situation of either fully implemented CPP, or positive attitudes of respondents towards CPP implementation.

An analysis of the reliability of our questionnaire's scales included questions from the third part of the Questionnaire as the first step (with the value of the Cronbach's Alpha being relatively high, 0.736). The Cronbach's Alpha values, by eliminating single questions, were in the range from 0.721 for question 18 , up to 0.802 for question 15 . The analysis of the change in the coefficient, by eliminating individual questions, proved to be very consistent and reliable for this part of the questionnaire, so there were no questions whose elimination would significantly increase the reliability coefficient of the entire scale. On the other hand, along with question 18, the elimination of questions 13 and 17 would have led to the largest decrease in the Cronbach's Alpha, making these questions the most valuable part of that questionnaire section.

Also, the values of the intraclass correlation coefficient were highly significant, which confirmed the compactness and high reliability of that part of the questionnaire (ICC $=0.749 ; \mathrm{p}<0.01)$.

\section{Factor analysis}

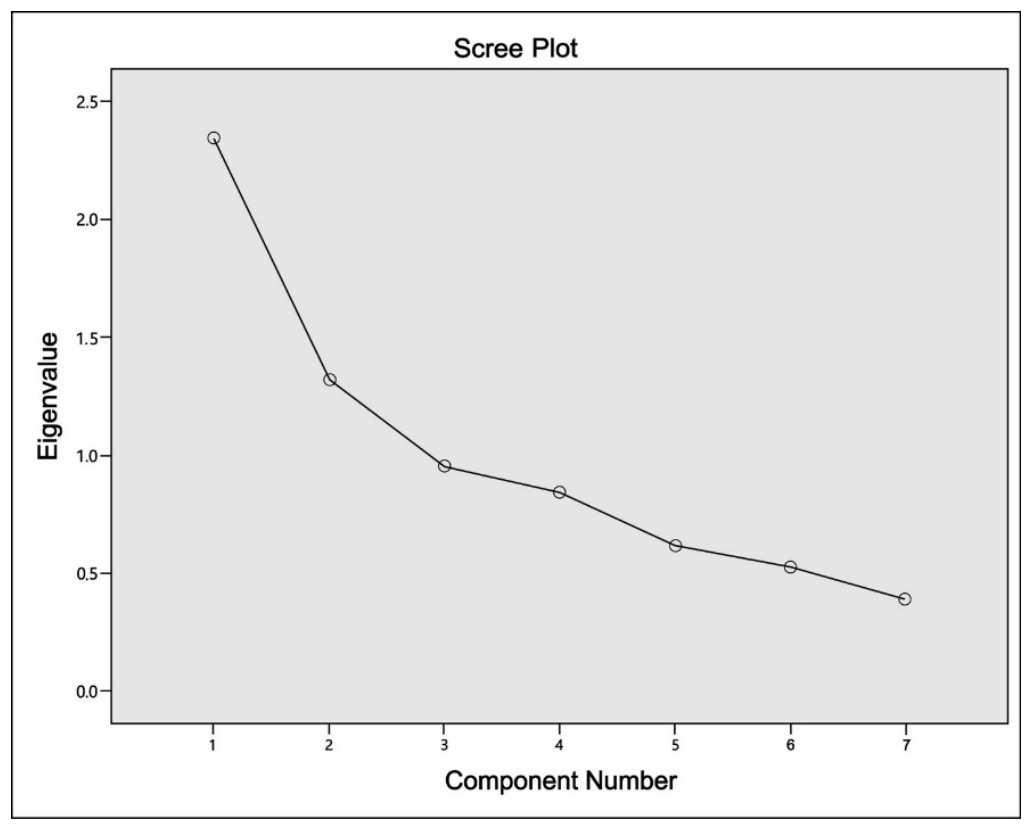

Figure 2. Load factors for questions 12-18

Slika 2. Faktorska opterećenja za pitanja 12-18 
Table II Rotated factor components for questions 12-18

Tabela II Faktorske rotirane komponente za pitanja 12-18

\begin{tabular}{|c|c|c|}
\hline \multirow{2}{*}{ Questions } & \multicolumn{2}{|c|}{ Factor components } \\
\cline { 2 - 3 } & 1 & 2 \\
\hline $\mathrm{q} 12$. & $\mathbf{0 . 7 6 6}$ & 0.149 \\
\hline $\mathrm{q} 13$. & $\mathbf{0 . 6 9 0}$ & -0.286 \\
\hline $\mathrm{q} 14$. & $\mathbf{0 . 7 4 4}$ & 0.223 \\
\hline $\mathrm{q} 15$. & 0.445 & $\mathbf{- 0 . 5 7 6}$ \\
\hline $\mathrm{q} 16$. & 0.137 & $\mathbf{0 . 6 7 0}$ \\
\hline $\mathrm{q} 17$. & $\mathbf{0 . 7 2 4}$ & 0.080 \\
\hline $\mathrm{q} 18$. & 0.126 & $\mathbf{0 . 6 2 0}$ \\
\hline
\end{tabular}

An Exploratory Factor Analysis (EFA) of that part of the questionnaire highlighted two significant factors, explaining approximately $53 \%$ of the variability of the entire model, with the first factor comprising questions $12,13,14$, and 17 . The second factor included questions 15, 16 and 18. Along with questions 12 and 14, questions 13 and 17 proved once again, according to that analysis as well, to be the most important part of the third section of the questionnaire, which included the testing of the conceptual model of collaborative pharmacy practice.

In section three of the questionnaire, there were no questions which were not classified by any of the selected factors.

\section{Correlation analysis}

Table III Statistical parameters of the question score correlation analysis for questions 12-18

Tabela III Statistički parametri analize povezanosti skorova pitanja 12-18

\begin{tabular}{|c|c|c|c|c|c|c|c|}
\hline \multicolumn{2}{|c|}{ Questions } & q12. & q13. & q14. & q15. & q16. & q17. \\
\hline \multirow{2}{*}{ q 13. } & $\mathrm{r}$ & $\mathbf{0 . 3 6 5}$ & & & & & \\
\cline { 2 - 8 } & $\mathrm{p}$ & $\mathbf{0 . 0 0 0 * *}$ & & & & & \\
\hline \multirow{3}{*}{ q 14. } & $\mathrm{r}$ & $\mathbf{0 . 5 6 3}$ & $\mathbf{0 . 2 4 3}$ & & & & \\
\cline { 2 - 9 } & $\mathrm{p}$ & $\mathbf{0 . 0 0 0 * *}$ & $\mathbf{0 . 0 0 1 * *}$ & & & & \\
\hline \multirow{2}{*}{ q 15. } & $\mathrm{r}$ & $\mathbf{0 . 1 3 7}$ & $\mathbf{0 . 4 0 3}$ & $\mathbf{0 . 1 3 9}$ & & & \\
\cline { 2 - 9 } & $\mathrm{p}$ & $\mathbf{0 . 0 5 4}$ & $\mathbf{0 . 0 0 0 * *}$ & $\mathbf{0 . 0 5 1 *}$ & & & \\
\hline \multirow{3}{*}{ q 16. } & $\mathrm{r}$ & 0.108 & 0.060 & $\mathbf{0 . 1 3 7}$ & -0.115 & & \\
\cline { 2 - 9 } & $\mathrm{p}$ & 0.140 & 0.412 & $\mathbf{0 . 0 5 2} *$ & 0.118 & & \\
\hline \multirow{2}{*}{ q 17. } & $\mathrm{r}$ & $\mathbf{0 . 4 1 3}$ & $\mathbf{0 . 3 7 4}$ & $\mathbf{0 . 4 1 8}$ & $\mathbf{0 . 1 7 2}$ & 0.027 & \\
\cline { 2 - 8 } & $\mathrm{p}$ & $\mathbf{0 . 0 0 0 * *}$ & $\mathbf{0 . 0 0 0 * *}$ & $\mathbf{0 . 0 0 0 * *}$ & $\mathbf{0 . 0 1 9 *}$ & 0.719 & \\
\hline \multirow{2}{*}{ q 18. } & $\mathrm{r}$ & 0.054 & -0.009 & 0.068 & -0.056 & $\mathbf{0 . 2 0 7}$ & $\mathbf{0 . 1 5 5}$ \\
\cline { 2 - 8 } & $\mathrm{p}$ & 0.461 & 0.907 & 0.354 & 0.450 & $\mathbf{0 . 0 0 5 * *}$ & $\mathbf{0 . 0 3 4 *}$ \\
\hline
\end{tabular}


We examined the correlation of the individual scores obtained from the third section of the questionnaire, by analyzing the correlations of the scores from our respondents' questionnaires, and it turned out that the question q12 was positively correlated with q13, q14, q15 and q17.

The analysis also showed a positive correlation between the individual scores of the question q13 and questions q14/q15/q17. There was a similar relation between q14 and questions p15, p16 and p17, such as between the individual scores of the q15 and q17. Further analysis found a correlation between the individual scores of q16 and q18, and the same relation between the scores of $\mathrm{q} 17$ and q18.

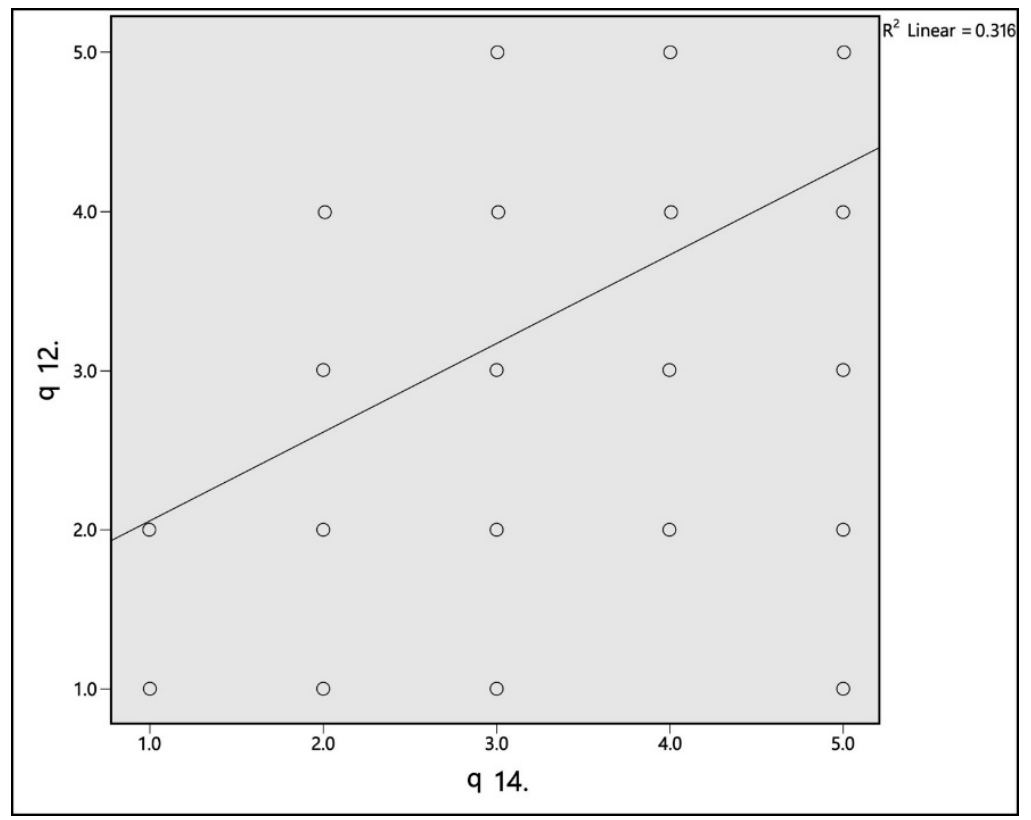

Figure 3. Question score correlation for questions 12 and 14

Slika 3. Povezanost skorova pitanja 12 i 14

\section{Discussion}

Despite the availability of various questionnaires for the assessment of CPP and IPC, measurement instruments with adequate psychometric properties are scarce. As Thannhauser J. and associates noted (7), there are several explanations for the numerous low quality quantitative research instruments for the evaluation of IPC: lack of a consistent vocabulary used; numerous perspectives on, and components of IPC; lack of consensus about what should be measured; and limited effort to develop the psychometric properties of the measurement tools that currently exist. The authors believe that the key problem is a lack of consistent vocabulary. The terms "collaboration", "interprofessional" and "interdisciplinary", although reflecting historical socialization and teamwork patterns (25), are now used interchangeably and with contemporary understandings. Without a consistent vocabulary and consensus about what should be measured, researchers are 
unable to focus their literature search and Boolean operators, and are therefore left with the options to develop their own questionnaire, or to avoid research in the area of CPP and IPC. Apart from targeting just one (interactional) factor that influences collaborative relationships (26), the development of instruments that focus on organizational and systemic factors is also needed (7) (Thannhauser J).

Therefore, the authors have developed their own questionnaire as a quantitative instrument for the purpose of this paper. A preliminary questionnaire validation conducted on a sample of 40 respondents (patients/users of the Geriatric Center) determined the value of the Cronbach's Alpha for the part of the questionnaire relating to the conceptual model of collaborative pharmacy practice to be high (0.774), while the value of the total sample $(n=185)$ was relatively high (0.736) (6). Additionally, the values of the intraclass correlation coefficient were highly significant, confirming the compactness and high reliability of that part of the questionnaire $(\mathrm{ICC}=0.749 ; \mathrm{p}<0.01)$. An analysis of the coefficient change by eliminating individual questions, confirmed that part of the questionnaire to be very consistent and reliable, and therefore not containing questions whose elimination would significantly increase the values of the reliability coefficient for the entire scale. The same analysis, together with the exploratory factor analysis, singled out questions $\mathrm{q} 12$ and $\mathrm{q} 14$, and 13 and 17, as the most important questions of that part of the questionnaire. An analysis of the questionnaire scores' correlation showed their clear relationship, and its results were presented in the part of the study dealing with results.

\section{Limitations and strengths}

An important limitation of the study has to do with the fact that all of the respondents (population 65+) were patients of five publicly owned geriatric centers in one country, and therefore, the study did not include senior responders living in their own homes, or responders from other countries. Additionally, apart from being validated through the Delphi method, the second part of the questionnaire has not been statistically tested due to the variety and nature of the questions where the Likert scale was not applicable. The strengths of the study include originality, rigorous methodology, the amount of data tested, and the fact that all the data used were primarily collected for the purpose of this study. The practical implication of the study is that it can be used as leverage for healthcare decision makers, and it is a usable tool for other healthcare researchers.

\section{Conclusion}

Since there had been no adequate survey instruments found in literature for research purposes, a questionnaire was developed and validated in order to examine the attitudes of senior citizens (as users of health and social services) regarding their "position" within the framework of health and social policy, together with their perception of the teamwork of health workers in the context of improving the quality of life of the elderly. When developed and validated, the questionnaire proved to be adequate for surveying the 
attitudes of the elderly on pharmacy collaborative practice, and in that regard, other researchers may use the questionnaire and compare their results with the results of the following cross-sectional study, conducted in Serbia by the same authors. Further practical implications can be found in drawing the awareness of researchers. Despite a consensus among researchers about patient and system benefits of CPP and IPC, comprehensive efforts to develop the psychometric properties of the measurement tools have been missing. Therefore, our developed questionnaire can be perceived as a contribution to the strong body of literature regarding collaborative healthcare practice, and a shared effort towards the development of a widely accepted questionnaire for measuring CPP and IPC.

\section{Conflict of interest}

The author(s) declared no potential conflict of interest with respect to the research, authorship and/or publication of this article.

\section{References}

1. Eurostat. Population structure and ageing. Luxembourg: Eurostat. 2017. [Cited 2018 July 27]. Available from:

http://ec.europa.eu/eurostat/statistics-explained/index.php/Population_structure_and_ageing.

2. United Nations. Department of Economic and Social Affairs, Population Division. World Population Ageing 2015. New York: United Nations. 2015. [Cited 2017 Apr 10] Available from: http://www.un.org/en/development/desa/population/publications/pdf/ageing/WPA2015_Report.pdf.

3. World Health Organization. Health aging topic. Geneva: World Health Organization. 2017. [Cited 2017 Sep 04]. Available from: http://www.who.int/topics/ageing/en/.

4. World Health Organization. Global strategy and action plan on aging and health (2016-2020): A Framework for Coordinated Global Action by the World Health Organization, Member States and Partners across the Sustainable Development Goals. Geneva: World Health Organization. 2016. [Cited 2018 Nov 29]. Available from: http://www.who.int/ageing/GSAP-Summary-EN.pdf?ua=1.

5. Ferrucci L, Giallauria F, Guralnik JM. Epidemiology of Aging. Radiol Clin North Am. 2008;46:643-652.

6. Ilić V, Tasić L, Marinković V. Research on the attitudes of the elderly towards interprofessional cooperation and collaborative pharmacy practices: Cross-sectional study in Serbia. Indian J Pharm Educ. 2021;55(1):276-87.

7. Thannhauser J, Russell-Mayhew S, Scott C. Measures of interprofessional education and collaboration. J Interprof Care. 2010;24:336-349.

8. Lindqvist S, Duncan A, Shepstone L, Watts F, Pearce S. Development of the "Attitudes to Health Professionals Questionnaire" (AHPQ): A measure to assess interprofessional attitudes. J Interprof Care. 2005; 19:269-279.

9. Körner M. Interprofessional teamwork in medical rehabilitation: a comparison of multidisciplinary and interdisciplinary team approach. Clin Rehabil. 2010;24:745-755. 
10. Parsell G, Bligh J. The development of a questionnaire to assess the readiness of health care students for interprofessional learning (RIPLS). Med Educ. 1999;33:95-100.

11. Ponzer S, Hylin U, Kusoffsky A, Lauffs M, Lonka K, Mattiasson AC, et al. Interprofessional training in the context of clinical practice: goals and students' perceptions on clinical education wards. Med Educ. 2004;38:727-736.

12. Rattray J, Jones MC. Essential elements of questionnaire design and development. J Clin Nurs. 2007;16:234-243.

13. Nuño Solinís R, Berraondo Zabalegui I, Sauto Arce R, San Martín Rodríguez L, Toro Polanco N. Development of a questionnaire to assess interprofessional collaboration between two different care levels. Int J Integr Care. 2013;13: e015.

14. Jokovic A, Locker D, Stephens M, Kenny D, Tompson B, Guyatt G. Validity and Reliability of a Questionnaire for Measuring Child Oral-health-related Quality of Life. J. Dent. Res. 2002;81:459463.

15. Juniper EF, Buist AS, Cox FM, Ferrie PJ, King DR.. Validation of a Standardized Version of the Asthma Quality of Life Questionnaire. Chest. 1999;115:1265-1270.

16. Black N, Varaganum M, Hutchings A. Relationship between patient reported experience (PREMs) and patient reported outcomes (PROMs) in elective surgery. BMJ Qual Saf. 2014;23:534-542.

17. Whelan P, Andrews T, Patel S, Lewis A. Taking the Cinderella speciality to the PROM: developing a patient related outcome measure for an older adult mental health service. Qual Ageing Older Adults. 2010;11:51-55.

18. Singer SJ, Burgers J, Friedberg M, Rosenthal MB, Leape L, Schneider E. Defining and Measuring Integrated Patient Care: Promoting the Next Frontier in Health Care Delivery. Med Care Res Rev. 2010;68:112-127.

19. Ilic V, Marinkovic V, Tasic L. Conceptual model of collaborative pharmaceutical practice in healthcare and social care for the elderly. Vojnosanit Pregl. 2018;75:1020-1029.

20. Diamond IR, Grant RC, Feldman BM, Pencharz PB, Ling SC, Moore AM, et al. Defining consensus: a systematic review recommends methodologic criteria for reporting of Delphi studies. Journal of clinical epidemiology. 2014 Apr 1;67(4):401-9.

21. Tsang S, Royse CF, Terkawi AS. Guidelines for developing, translating, and validating a questionnaire in perioperative and pain medicine. Saudi journal of anaesthesia. 2017 May;11(Suppl 1):S80.

22. Perneger TV, Courvoisier DS, Hudelson PM, Gayet-Ageron A. Sample size for pre-tests of questionnaires. Quality of Life Research. 2015 Jan;24(1):147-51.

23. Pejin SL, Bajec J. ESPN Thematic Report on Challenges in long-term care-Serbia. Brussels: European Commission. 2018. [cited 2020 May 2]. Available from: https://ec.europa.eu/social/main.jsp?pager.offset=20\&catId=792\&langId=en\&moreDocuments=yes.

24. Sauer M, Perišić N. Local Networks in the Provision of Long-term Care Services in Serbia - a View from the South-East of Europe. Sozialer Fortschritt. 2014;63(8):209-15.

25. Mccallin A. Interdisciplinary practice - a matter of teamwork: an integrated literature review. J Clin Nurs. 2001;10:419-428.

26. San Martín-Rodríguez L, Beaulieu M-D, D’Amour D, et al. The determinants of successful collaboration: A review of theoretical and empirical studies. J Interprof Care. 2005;19:132-147. 


\title{
Stavovi starijih osoba prema interprofesionalnoj kooperaciji i kolaborativnoj farmaceutskoj praksi: Razvoj upitnika
}

\author{
Velibor O. Ilić ${ }^{1 *}$, Ljiljana Tasić ${ }^{1}$, Valentina Marinković ${ }^{1}$ \\ ${ }^{1}$ Univerzitet u Beogradu - Farmaceutski fakultet, Katedra za socijalnu farmaciju i \\ farmaceutsko zakonodavstvo, Vojvode Stepe 450, 11221 Beograd, Srbija
}

* Autor za korespondenciju: Velibor O. Ilić, E-mail: ivelibor@gmail.com.

\section{Kratak sadržaj}

Starenje populacije se odvija po najvišoj stopi u istoriji, vodeći do povećanja morbiditeta. Stoga se od povećanja nivoa kolaborativne farmaceutske prakse (CPP) i interprofesionalne kolaboracije (IPC) očekuje da dovedu do neophodnog povećanja performansi sistema zdravstvene zaštite. Da bi se poboljšala literatura fokusirana na CPP i IPC, neophodno je da se sprovode istraživačke studije sa jasno definisanim metodama, koje koriste upitnike dobro razvijenih psihometrijskih karakteristika. S tim u vezi, cilj studije je bio da se razvije upitnik za istraživanje stavova starijih osoba $(65+)$ prema IPC i CPP. Koristeći Delfi metod, tim stručnjaka $(n=8)$ je tokom četiri sastanka razvio strukturirani upitnik. Analiza pouzdanosti, korelacija pitanja i faktorska analiza bile su korišćene za validaciju upitnika. Validacija upitnika $(n=40)$ utvrdila je visoku vrednost Kronbahovog koeficijenta od 0.774 , dok je analiza pouzdanosti skala na ukupnom uzorku ( $\mathrm{n}=185)$ prikupljenom iz pet Gerontoloških centara potvrdila relativno visoku vrednost Kronbahovoh koeficijenta od 0.736 . Vrednosti intraklasnog koeficijenta korelacije bile su visoko značajne ( $\mathrm{ICC}=0.749 ; \mathrm{p}<0.01$ ), što potvrđuje kompaktnost i visoku pouzdanost ovog dela upitnika. Eksploratorna faktorska analiza (EFA) izdvojila je 2 značajna faktora koji objašnjavaju približno 53\% varijabiliteta celog modela. Prikladnost razvijenog upitnika potvrđena je validacijom upitnika $(n=40)$ i analizom na ukupnom uzorku $(n=185)$.

Ključne reči: razvoj upitnika, kolaborativna praksa, stavovi starijih osoba, Delfi metod 


\section{Supplementary material}

General attitudes and viewpoints regarding improving the quality of life of seniors and within the context of upgrading the performance of the Health- and Social Care for the elderly

\section{Survey - Part one: "General Demographic Issues"}

Provide your honest answers to all questions by crossing out the circles in front of the answers or by writing down a response (one answer per question only).

\begin{tabular}{|l|l|l|}
\hline 1. Gender: & O female $\quad$ male \\
\hline 2. Your age: & \multicolumn{2}{l|}{} \\
\hline 3. Education: & $\begin{array}{l}\text { O High school degree } \\
\text { O Associate degree } \\
\text { O Bachelor's Degree }\end{array}$ & $\begin{array}{l}\text { O Specialization } \\
\text { O Master's degree } \\
\text { O Doctoral degree }\end{array}$ \\
\hline
\end{tabular}

\section{Instructions for completing the survey:}

Provide your answers by crossing out the circle in front of the applicable answer. If the question requires more responses, rank your answers by significance, marking the circles in front of appropriate numbers, e.g. : from 1 to 5 ( with number 1 indicating your first, and most significant answer). Questions with the ranking requirement are marked with $\operatorname{asterisks}(* * *)$. 


\section{Survev-Section two: "Elderlv People's views on Healthcare and Social Policies"}

1) Are you familiar with options which the Office for the Elderly could ž provide?

OYes O No

2) What new services can you suggest to the Office for the Elderly?

O Information distributor $\mathrm{O}$ Family educator $\mathrm{O}$ Legal adviser

O Volunteering initiator $\quad O$ Driver of Development of the Protection of the Elderly Strategy

$\mathrm{O}$ Initiator of an increase in Geriatric Center accommodation capacity

O None of the above

3) $\left({ }^{* * *}\right)$ Rank your answers from 1 to 6 , according to the importance of the service that the Office for the Elderly would provide (enter numbers from 1 to 6 , respectively, in the circle next to the applicable answer, indicating your first and most important answer with 1)

O Information distributor $\quad \mathrm{O}$ Family educator $\mathrm{O}$ Legal adviser

O Volunteering initiator O Driver of Strategy Development for the Protection of the Elderly

$\mathrm{O}$ Initiator of an increase in Geriatric Center accommodation capacity

4) Where (what source) do you collect data from most frequently, regarding services of the Health- and Social Care, as well the options it provides to you? Mark one answer only.
O From friends
O From TV
O From newspapers or info newsletters
O From a Retirees Association O From another source
O From a health care facility (pharmacy, community healthcare facility)

5a) What health- or social care service have you used the most in the last year? Mark one answer only.

O Advice on proper drug use $\quad$ O Geriatric Aide services

O Home Health Care Services O Advisory services related to social and health care legislation

5b) Can you express the level of your satisfaction with the services listed above and provided within the Health- and Social Care?

(Indicate your answers by crossing out one circle on a scale from 1 to 5; indicating your lowest satisfaction level with 1 and indicating your highest satisfaction level with 5. .)
01
02
03
04
05

(Very disatisfied) (Disatisfied) (Moderately satisfied) (Satisfied) (Very satisfied) 
6) Which of the above mentioned services from the domain of the health- and social care should be managed by the Office for the Elderly, according to your opinion? Mark one answer only
O Geriatric Aide services
O Nursing care at home services
O Accommodation services
O Senior day care
O Financial assistance
O Patient medication counseling

7) (***) Rank your answers from 1 to 6 , according to importance of the issues the elderly are faced with within the scope of Health - and Social Policy (enter numbers from 1 to 6 respectively, in the circle in front of the applicable answer, marking your first and most important answer with 1).
O Insufficient "visibility" of the elderly
$\mathrm{O}$ Inefficient informing
O Insufficient accommodation capacity of the Geriatric Center
$O$ Insufficient volunteering
O Rigidity of the Health care system
$O$ Insufficient range of services

8) What do you consider to be the biggest barrier to the adoption and implementation of the Health and Social Care Policy for the Elderly? Mark one answer only.
O Lack of financial resources
O Insufficient political will
$\mathrm{O}$ Lack of staffing
O Insufficient coordination
O Untimely informing
$\mathrm{O}$ Indifference of the society at large

9a) Have you participated in a volunteering activity?
O Yes
O No

9b) Would you join a volunteering activity geared towards improving the quality of life of the elderly?

(Indicate your answers by crossing out one circle on a scale from 1 to 5; indicating your lowest satisfaction level with 1 and indicating your highest satisfaction level with 5.)
01
02
03
04
05

10) Choose one of the listed institutions (organizational units), which would contribute best to improving the quality of the Health Care of the Elderly, according to your opinion.

O Geriatrics Institute (a form of health care facility for the elderly)

O Geriatric hospital (treating age-related diseases and providing physical therapy rehabilitation for the elderly)

O Hospice (a form of palliative care)

O Specialized Counseling Centers (Community Health Centers and Pharmacy) for the health care of the elderly

11) Which of the following items do you suggest should be improved, so that your place of residence may become the place of the people with "equal opportunities"? Mark one answer only.

O Social aspects O Educational/cultural aspects O Health aspects

$\mathrm{O}$ Other aspects $\mathrm{O}$ Economic aspects $\quad \mathrm{O}$ Sport and Recreation Facilities 


\section{Survev - Section three: "Health workers teamwork in the context of improving the quality of life of the elderly"}

Indicate your answer by crossing out a single circle on a scale of 1 to 5 for each question. With 1 indicating your lowest level of agreement with a listed statement, and with 5 indicating the highest level of agreement with that statement, or question (e.g.: 1 Very bad, 2 - bad, 3- Good, 4 -Very good, 5 -Excellent).

12) Would a pharmacist, as a part of the health care workers team, providing care for the elderly, improve health-related outcomes and quality of life of the elderly?

$\begin{array}{lllll}01 & 02 & 03 & 04 & 05\end{array}$

$\begin{array}{llll}\text { (Not at all) (Very little) } & \text { (Possibly) } & \text { (Very much) }\end{array}$

13) How would you rate the information provided by doctors and pharmacists regarding products (drugs, medical devices, and dietary supplements) prescribed/recommended to elderly patients?

$\begin{array}{lllll}01 & 02 & 03 & 04 & 05\end{array}$
(Very poor)
(Poor)
(Good)
(Very good)
(Excellent)

14) According to your opinion, would the efficiency of the Health Care improve, if pharmacists provided counseling services regarding the rational and safe use of pharmaceutical products (drugs, medical devices and dietary supplements) for the elderly patients?

$\begin{array}{lllll}01 & 02 & 03 & 04 & 05\end{array}$
(Not at all)
(Very little)
(Possibly)
(Very much)
(Significantly)

15) How would you assess the efficiency of the Health Care System in regards to the time spent on prescribing and issuing pharmaceutical products to the elderly

$\begin{array}{lllll}01 & 02 & 03 & 04 & 05\end{array}$

$\begin{array}{llll}\text { (Very low }) & \text { (Low) } & \text { (Medium) }\end{array}$

16) Have you ever experienced a scenario at the pharmacy, where a pharmacist notices a certain oversight in the doctor's prescription/recommendation for a product to elderly patients (medicines, medical devices and dietary supplements) and asks you to return to your doctor in order to have him/her correct the error or to have the therapy revised?
01
02
03
04
05
(Rarely)
(Sometimes)
(A few times) (Frequently)

(Never)

17) Would you think that the efficiency of the Healthcare system would increase if there were an even better cooperation and coordination between doctors and pharmacists and other health care workers providing care for the elderly?
01
02
03
04
05
(Not at all)
(Very little)
(Possibly)
(Vey much)
(Significantly) 
18) Have you experienced a power outage or a computer system crash at the Community Health Care Center or a pharmacy?

01

02

03

04

05

(Never)

(Rarely)

(Sometimes)

(A few times)

(Frequently)

19) If you were in the situations as described in question number 18, how were the situations resolved at the Community Health Care Center most typically? (Mark one answer only)

O We were asked to hold on

O We were told to come back later

O A doctor prescribed the therapy

$\mathrm{O}$ A doctor contacted the pharmacist to have him/her check the database for the medicines the patient uses

20) If you were in the situation described in question number 18 , how were the situations resolved at the pharmacy most typically (Mark one answer only)?

O We were asked to hold on

O We were told to come back later

O The pharmacist dispensed the therapy

WE APPRECIATE YOUR TIME AND EFFORT! 